Article

\title{
Features of the Molecular Structure and Luminescence of Rare-Earth Metal Complexes with Perfluorinated (Benzothiazolyl)phenolate Ligands
}

\author{
Tatyana V. Balashova ${ }^{1, *}$, Mikhail E. Burin ${ }^{1}$, Vasily A. Ilichev ${ }^{1}$, Alyona A. Starikova ${ }^{2} \mathbb{E}$, \\ Alexey V. Marugin ${ }^{3}{ }^{(D)}$, Roman V. Rumyantcev ${ }^{1}{ }^{1}$, Georgy K. Fukin ${ }^{1}$, Artem N. Yablonskiy ${ }^{4}$, \\ Boris A. Andreev ${ }^{4}(\mathbb{D}$ and Mikhail N. Bochkarev 1,3,* \\ 1 G. A. Razuvaev Institute of Organometallic Chemistry of Russian Academy of Sciences, Tropinina street, 49, \\ 60313 Nizhny Novgorod, Russia \\ 2 Institute of Physical and Organic Chemistry, Southern Federal University, Stachka avenue 194/2, \\ 344090 Rostov-on-Don, Russia \\ 3 Nizhny Novgorod State University, Gagarina avenue 23/2, 603950 Nizhny Novgorod, Russia \\ 4 Institute for Physics of Microstructures of Russian Academy of Sciences, Akademicheskaya street 7, \\ 603950 Nizhny Novgorod, Russia \\ * Correspondence: petrovsk@iomc.ras.ru (T.V.B.); mboch@iomc.ras.ru (M.N.B.); \\ Tel.: +7-(831)-435-4021 (M.N.B.)
}

Academic Editor: M. Concepción Gimeno

Received: 28 May 2019; Accepted: 24 June 2019; Published: 27 June 2019

Abstract: A set of Sc, Nd, Sm, Eu, Ho, Gd, Er, Yb complexes with perfluorinated 2-(benzothiazol2-yl)phenolate ligands $\operatorname{Ln}\left(\mathrm{SON}^{\mathrm{F}}\right)_{3}(\mathrm{DME})$ were synthesized by the reactions of silylamides $\mathrm{Ln}\left[\mathrm{N}\left(\mathrm{SiMe}_{3}\right)_{2}\right]_{3}$ with phenol $\mathrm{H}\left(\mathrm{SON}^{\mathrm{F}}\right)$. The structure of the initial phenol, $\mathrm{Sc}$, and Er complexes was established using X-ray analysis, which revealed that the obtained compounds are mononuclear, in contrast to the binuclear non-fluorinated analogues $\left[\operatorname{Ln}(\mathrm{SON})_{3}\right]_{2}$ synthesized earlier. All the obtained complexes, both in solid state and in tetrahydrofuran (THF) solutions, upon excitation by light with $\lambda_{\text {ex }} 395$ or $405 \mathrm{~nm}$ show intense luminance of the ligands at $440-470 \mathrm{~nm}$. The Eu complex also exhibits weak metal-centered emission in the visible region, while the derivatives of Sm luminesces both in the visible and in the infrared region, and $\mathrm{Nd}, \mathrm{Er}$, and $\mathrm{Yb}$ complexes emit in the near IR (NIR) region of high intensity. DFT (density functional theory) calculation revealed that energy of frontier orbitals of the fluorinated complexes is lower than that of the non-fluorinated counterparts. The level of highest occupied molecular orbital (HOMO) decreases to a greater extent than the lowest occupied molecular orbital (LUMO) level.

Keywords: lanthanides; photoluminescence (PL); fluorinated benzothiazolate ligands; excited state lifetime

\section{Introduction}

The search for new efficient photo- and electroluminophores still remains an urgent task. Near infrared (NIR) luminescence, especially from lanthanide complexes, such as $\mathrm{Nd}^{3+}$ and $\mathrm{Yb}^{3+}$, has emerged as an area of paramount interest due to its pioneering technological applications in fields ranging from bioimaging to optical communications [1-7]. However, since f-f transitions are largely forbidden, the ligand-free $\mathrm{Ln}^{3+}$ ions have very low molar absorption coefficients and hence the direct excitation of lanthanide ions always leads to modest or low luminescent intensities [8-15]. This problem can be solved with the help of organic ligands, which harvest excitation energy and transfer it to the attached $\mathrm{Ln}^{3+}$ ion, significantly increasing its luminescence (antenna effect) [16-19]. One of the most promising harvesting compounds is the benzothiazolate ligand (SON). The lanthanide complexes with 
SON ligands display excellent photo- and electroluminescence properties [20,21]. All these compounds, except for the scandium complex, have a dimeric structure, and all the ligands are bidentate [20,21]. However, the high energy of their triplet level does not coincide too much with the first excited state of NIR-luminescent ions $\mathrm{Ln}^{3+}$ [22]. As is known, the replacement of $\mathrm{C}-\mathrm{H}$ bonds in a ligand with low energy $\mathrm{C}-\mathrm{F}$ oscillators is able to lower the vibrational energy of the ligand and thereby enhances the luminescence intensity of the $\mathrm{Ln}^{3+}$ ions, especially for NIR emitting metals [23,24]. This effect is well manifested in $\mathrm{Zn}$ complexes with fluorinated benzothiazolate ligands, which show intense photoluminescence [25]. Following this approach, in search of new effective phosphors, we synthesized complexes of rare-earth metals based on perfluorinated benzothiazolate ligands $\left(\mathrm{SON}^{\mathrm{F}}\right)$ and studied their structure and photoluminescent (PL) properties.

\section{Results and Discussion}

\subsection{Synthesis}

The reactions of phenol $\mathrm{H}\left(\mathrm{SON}^{\mathrm{F}}\right)$ with silylamides of rare-earth metals in a molar ratio of 3:1 (Scheme 1) occur readily at room temperature in a 1,2-dimetoxyethane (DME) solution and afford the expected products as light-yellow, yellow, or light-green finely crystalline powders in $65-78 \%$ yields.

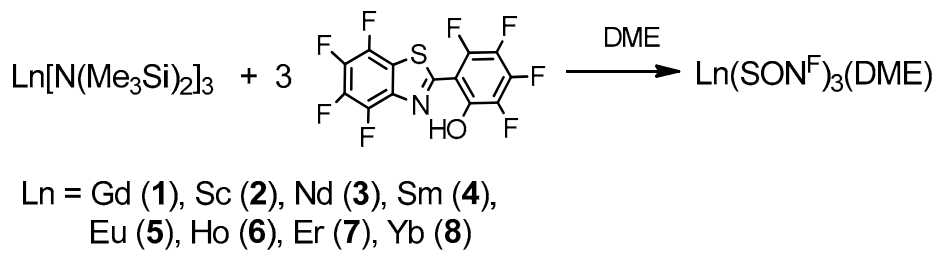

Scheme 1. Synthetic scheme for complexes 1-8.

A TGA study of the europium complex $\mathrm{Eu}\left(\mathrm{SON}^{\mathrm{F}}\right)_{3}(\mathrm{DME})$, as an example, showed that compounds with fluorinated ligands are less thermally stable than their non-fluorinated analogues (Figure 1).

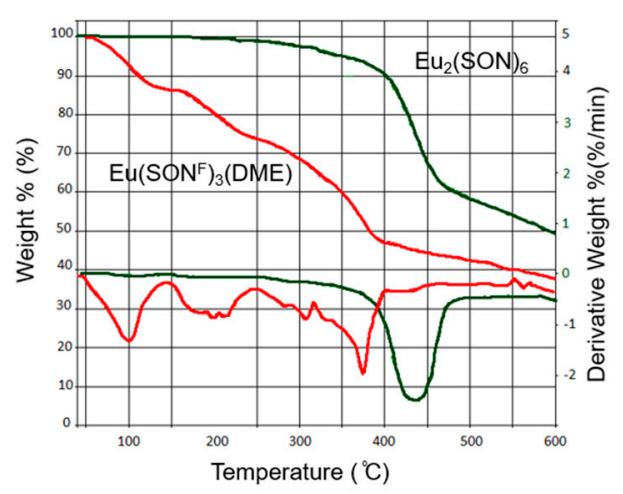

Figure 1. TGA of complexes $\mathrm{Eu}\left(\mathrm{SON}^{\mathrm{F}}\right)_{3}(\mathrm{DME})$ - red, and $\mathrm{Eu}_{2}(\mathrm{SON})_{6}$-green.

\subsection{Crystal Structures of $H\left(S O N^{F}\right), 2$ and 7}

According to the $\mathrm{X}$-ray diffraction data, the asymmetric unit of the $\mathrm{H}\left(\mathrm{SON}^{\mathrm{F}}\right)$ compound contains two disordered independent molecules, which have close geometric parameters. Molecules have a practically flat structure. The dihedral angles between benzothiazole and hydroxyphenyl fragments are $1.09-7.35^{\circ}$. This feature is in excellent agreement with previously published non-fluorinated analogues [26-28]. Such conformation, similar to non-fluorinated analogues [26-29], is stabilized by an intramolecular hydrogen bond $\mathrm{O}(1) \mathrm{H}(1) \cdots \mathrm{N}(1)$ [1.71(2) $\mathrm{A}]$ (Figure 2). 


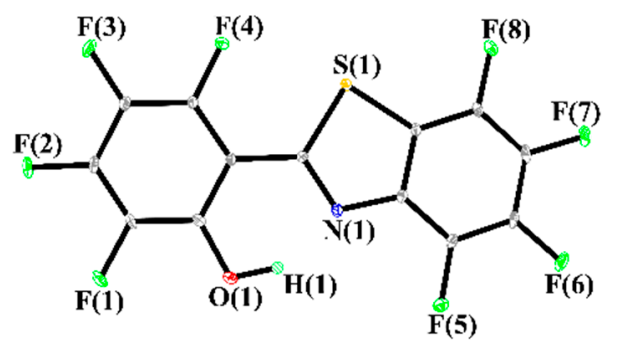

Figure 2. Molecular structure of independent molecules of $\mathrm{H}\left(\mathrm{SON}^{\mathrm{F}}\right)$ (thermal ellipsoids are drawn at $30 \%$ probability).

In a crystal, $\mathrm{H}\left(\mathrm{SON}^{\mathrm{F}}\right)$ molecules form endless stacks with a frontal orientation (Figure $\mathrm{S} 1$ ). The dihedral angles between the planes of phenolate and five-membered heterocycles of neighboring ligands are $0.36-4.48^{\circ}$, and the distances between the centers of these fragments are $3.616-3.815 \AA$. These geometrical parameters are appropriate for the realization of intramolecular $\pi \cdots \pi$ interactions [29]. The angles between the molecules of the neighboring infinite stacks are $48.37-49.17^{\circ}$ (Figure S1).

According to $\mathrm{X}$-ray analysis, complex 2 contains three $\mathrm{SON}^{\mathrm{F}}$ anionic ligands and one neutral molecule, DME, coordinated to the Sc atom, which has a distorted pentagonal bipyramidal environment (Figure 3). It should be noted that two ligands in 2 are bonded to the Sc(1) atom monodentately via oxygen atoms. The sulfur atoms of the benzothiazolyl fragments in these ligands are directed towards the metal atom but do not interact coordinately. In turn, the third $\mathrm{SON}^{\mathrm{F}}$ ligand coordinates to the $\mathrm{Sc}(1)$ atom bidentately via oxygen and nitrogen atoms. Such coordination was previously observed in a complex of yttrium with a 3-(2-benzothiazol-2-yl)-2-naphtholate ligand [30]. Analysis of Sc(1) coordination environment has shown the existence of the intramolecular $\mathrm{Sc}(1) \cdots \mathrm{F}(8)$ interaction, which is $2.782 \AA$ (Figure 3).

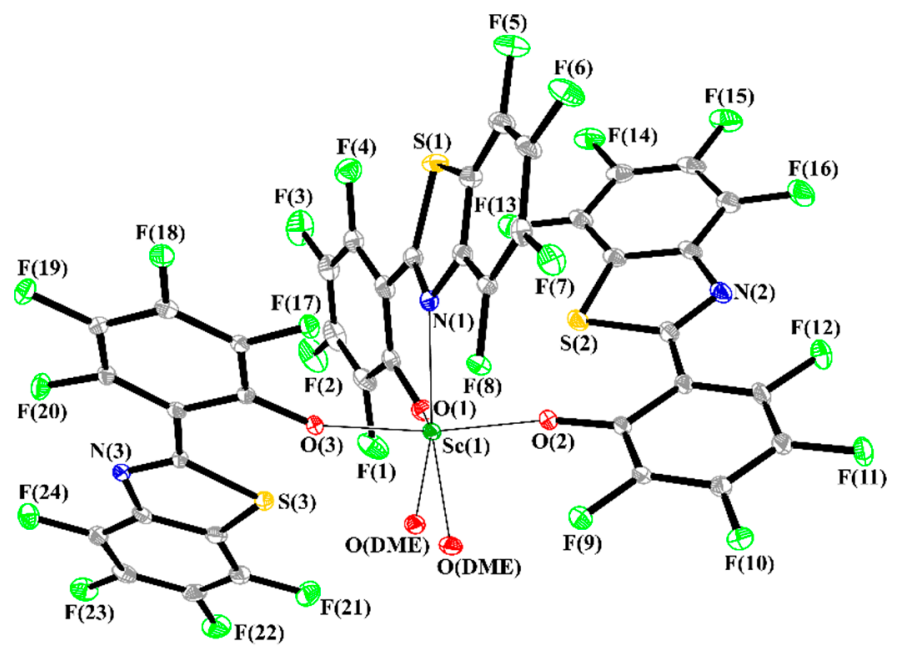

Figure 3. Molecular structure of 2 (thermal ellipsoids are drawn at 30\% probability; DME molecule is presented only $\mathrm{O}$-atoms for clarity). Selected distances $(\AA)$ and angles $\left(^{\circ}\right)$ in 2: $\mathrm{Sc}(1)-\mathrm{O}(3)$ 2.012(4), $\mathrm{Sc}(1)-\mathrm{O}(1)$ 2.021(4), Sc(1)-O(2) 2.011(4), Sc(1)-O(4) 2.254(4), Sc(1)-O(5) 2.263(4), Sc(1)-N(1) 2.297(5), $\mathrm{Sc}(1)-\mathrm{F}(8)$ 2.782; $\mathrm{O}(3)-\mathrm{Sc}(1)-\mathrm{O}(1)$ 90.12(16), O(3)-Sc(1)-O(2) 168.60(17), O(1)-Sc(1)-O(2) 94.97(17), $\mathrm{O}(3)-\mathrm{Sc}(1)-\mathrm{N}(1)$ 85.80(15), O(1)-Sc(1)-N(1) 78.66(17), O(2)-Sc(1)-N(1) 85.21(16).

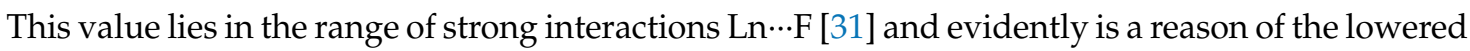
thermostability of the complexes obtained. The calculation executed by the ToposPro program [32] confirms the $\mathrm{Sc}(1) \cdots \mathrm{F}(8)$ interaction and denotes the absence of Sc‥S ones in 2 . The solid angle corresponding to the $\mathrm{Sc}(1) \cdots \mathrm{F}(8)$ interaction is $6.9 \%$. Two monodentately coordinated $\mathrm{SON}^{\mathrm{F}}$ ligands in 2 are practically flat. The dihedral angles between benzothiazole and hydroxyphenyl fragments are 2.30 and $6.89^{\circ}$. In turn, the planarity of the bidentately coordinated $\mathrm{SON}^{\mathrm{F}}$ ligand is largely 
distorted (the same angle is $20.02^{\circ}$ ). The conformation of the $\mathrm{SON}^{\mathrm{F}}$ ligand is typical for related complexes [21,30,33-35]. The planes of monodentately coordinated $\mathrm{SON}^{\mathrm{F}}$ ligands of neighboring molecules are parallel to each other, which indicates the $\pi \cdots \pi$ interactions in crystal between these groups (Figure S2) [29].

In complex 7 , the erbium atom is coordinated by three monodentate $\mathrm{SON}^{\mathrm{F}}$ anionic ligands and four neutral methanol molecules (Figure 4). As in complex 2, in the molecule of $\mathbf{7}$ there are shortened Ln $\cdots \mathrm{F}$ contacts $(\operatorname{Er}(1) \cdots \mathrm{F}(17) 3.107 \AA)$, which decrease its thermostability. According to calculations executed by the ToposPro program [32], the solid angle of this interaction is $3.4 \%$. The coordination environment of the $\operatorname{Er}(1)$ cation is a distorted square antiprism, $\mathrm{CN}$ is 8 .

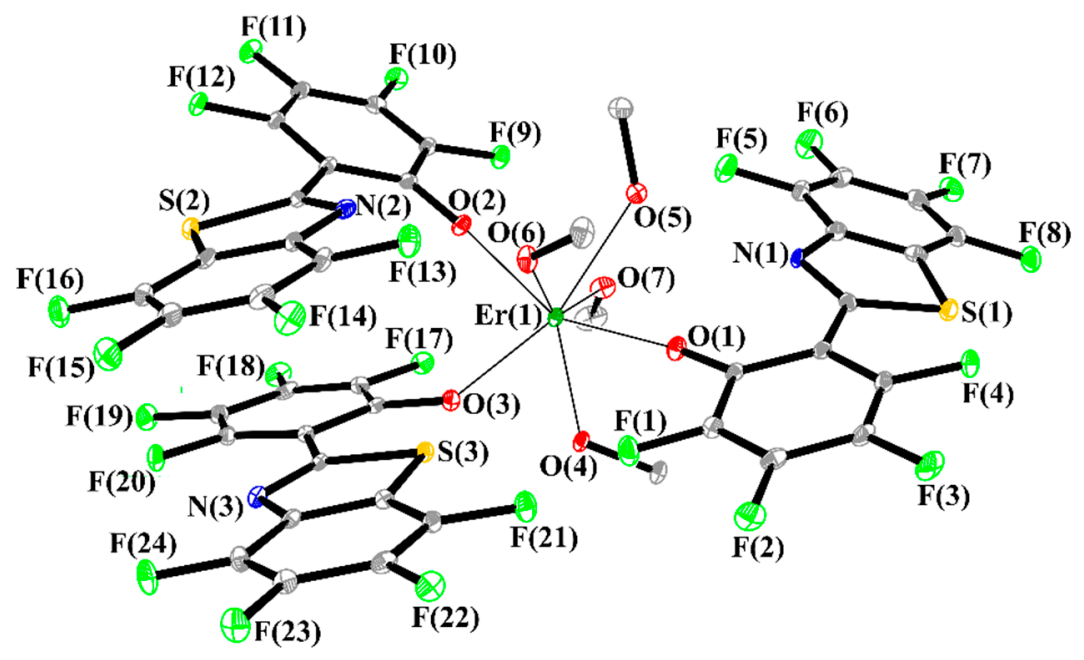

Figure 4. Molecular structure of 7 (thermal ellipsoids are drawn at 30\% probability; hydrogen atoms are omitted for clarity). Selected distances $(\AA)$ and angles $\left(^{\circ}\right)$ in $7: \operatorname{Er}(1)-O(1) 2.177(2), \operatorname{Er}(1)-O(2)$ 2.1782(19), $\mathrm{Er}(1)-\mathrm{O}(3)$ 2.226(2), $\mathrm{Er}(1)-\mathrm{F}(17)$ 3.107; O(1)-Er(1)-O(2) 147.51(8), O(1)-Er(1)-O(3) 115.32(8), $\mathrm{O}(2)-\mathrm{Er}(1)-\mathrm{O}(3)$ 85.20(8).

It should be pointed out that in complex 7 all SON ${ }^{\mathrm{F}}$ ligands are coordinated with the metal atom monodentally. Moreover, the ligands in the molecule have a different orientation: one of them is located in such a way that the nitrogen atom of the thiazole ring is directed to the metal atom, but the other two ligands are rotated so that the sulfur atom is closer to the Ln center. The monodentate coordination mode, observed as well in complex $\mathbf{2}$, is unusual for non-fluorinated bensothiasolates and similar complexes. The difference in the structure of fluorinated and non-fluorinated compounds is explained evidently by the coordination between the Ln ion and the fluorine atoms, which occupy the coordination sphere of the metal atom and interfere with the coordination of the $\mathrm{N}$ and $\mathrm{S}$ atoms. Er $\cdots \mathrm{S}$ $(\mathrm{O}, \mathrm{N})$ distances in 7 exceed the corresponding values in 2 , which agrees well with the difference in the cationic radii of $\mathrm{Sc}^{3+}$ and $\mathrm{Er}^{3+}$ [36]. Molecules of complex 7 in a crystal form dimeric pairs (Figure S3). The inter- and intramolecular distances between centers of aromatic systems of $\mathrm{SON}^{\mathrm{F}}$ ligands are 3.483 $\AA$ and 3.482-3.758 $\AA$, respectively, which indicates the existence of $\pi \cdots \pi$ interactions [29]. Besides this, in a crystal there is intermolecular $\mathrm{N} \cdots \mathrm{H}$ interactions $(2.226 \AA)\left(\mathrm{R}(\mathrm{N})_{\mathrm{vdw}}=1.60 \AA, \mathrm{R}(\mathrm{H})_{\mathrm{vdw}}=1.01 \AA\right)$ (Figure S3) [37].

\subsection{Absorption Spectra and Judd-Ofelt Analysis}

It is known that 2-(2-hydroxyphenyl)benzothiazole and respective benzothiazolate ligands can exist in enol and keto forms, which affects their molecular structure and electronic absorption spectra $[34,38,39]$. This feature is also inherent in perfluorated analogues, which is confirmed by their electronic absorption spectra in THF solutions. The spectra consist of three bands in the regions 250-310, $320-370$, and $380-420 \mathrm{~nm}$ (Figure 5) and are assigned to intraligand $\pi-\pi^{*}$ transitions. Their relative intensity reflects the ratio of tautomeric forms in the compounds $[34,39]$. The spectra of complexes 
also contain two bands caused by intramolecular $\pi-\pi^{*}$ transitions. The observed bathochromic shift of the long-wavelength band in the spectra of the $\mathrm{Nd}, \mathrm{Sm}, \mathrm{Eu}$, and $\mathrm{Gd}$ complexes compared to the Sc, $\mathrm{Ho}, \mathrm{Er}$, and $\mathrm{Yb}$ spectra is probably explained by some changes in the geometry of the coordination environment of metal ions upon transition from small to large $\mathrm{Ln}^{3+}$ ions.

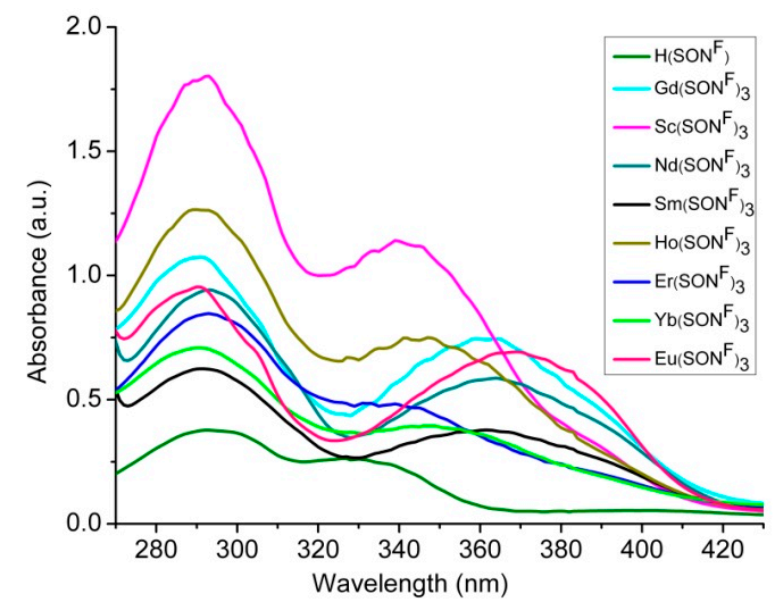

Figure 5. Absorption spectra of ligand $\mathrm{H}\left(\mathrm{SON}^{\mathrm{F}}\right)$ and complexes 1-8 in THF solutions.

To evaluate the calculated luminescent lifetime of the obtained complexes using the Judd-Ofelt theory, the spectrum of the solutions of compound 4 in THF in the NIR region was recorded using the compensatory subtraction method [40] (Figure 6). The spectrum consisted of six peaks assigned to $\mathrm{f}$-f transitions from the ground ${ }^{6} \mathrm{H}_{5 / 2}$ state to the excited ${ }^{6} \mathrm{~F}_{\mathrm{J}}(\mathrm{J}=11 / 2,9 / 2,7 / 2,5 / 2,3 / 2,1 / 2)$ and ${ }^{6} \mathrm{H}_{15 / 2}$ energy levels (transitions from ${ }^{6} \mathrm{H}_{5 / 2}$ to states ${ }^{6} \mathrm{~F}_{3 / 2}$ and ${ }^{6} \mathrm{H}_{15 / 2}$ are combined in a single spectral peak).

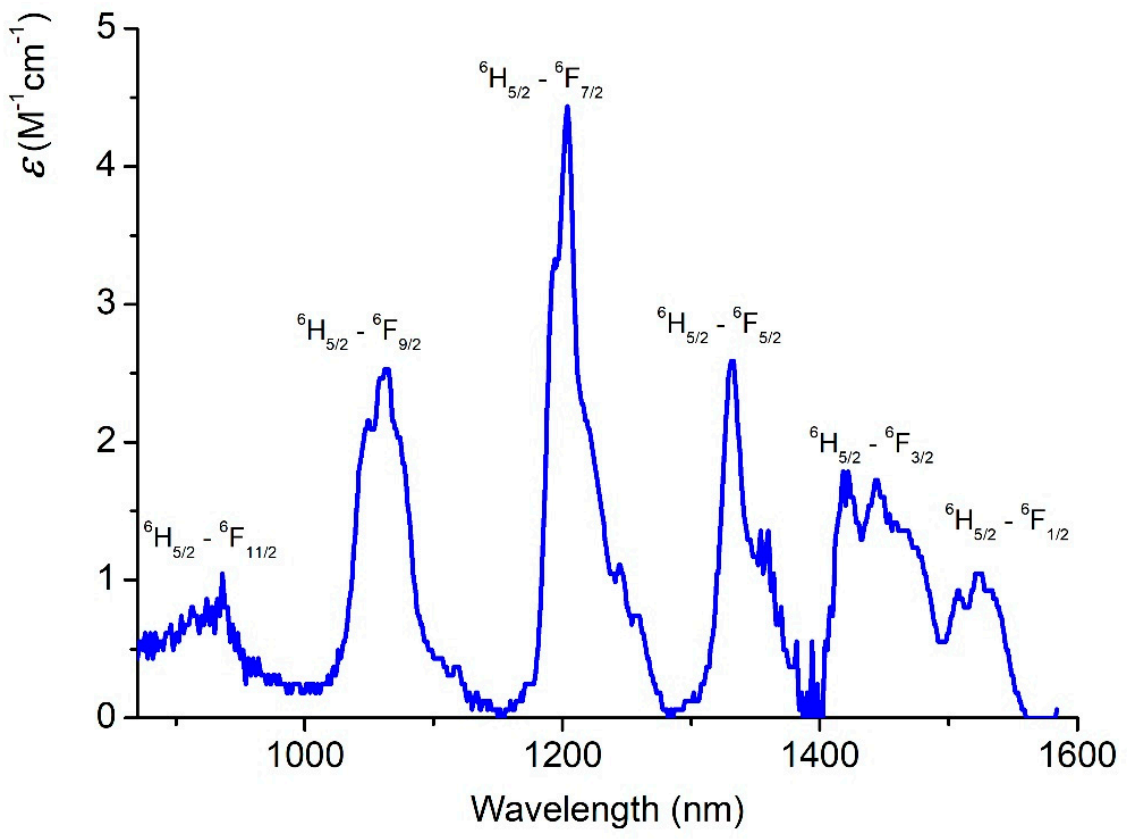

Figure 6. NIR absorption spectrum of complex 4 in THF solution.

Based on six absorption bands in the NIR region, the experimental values of line strength for each band were determined. Statistical analysis of the absorption spectra using the regression method yielded the Judd-Ofelt intensity parameters $\Omega_{2}, \Omega_{4}$, and $\Omega_{6}$, which indicate the intensity of metal-centered emission in the presence of a ligand. The values were found to be $\Omega_{2} \approx 1.838, \Omega_{4} \approx 1.792$, and $\Omega_{6} \approx 2.320\left(\times 10^{-20}\right) \mathrm{cm}^{2}$ with the error RMS Error $=0.115 \times 10^{-20} \mathrm{~cm}^{2}$. Similar estimates of 
Judd-Ofelt parameters $\Omega_{2}, \Omega_{4}$, and $\Omega_{6}$ indicate an approximately equal contribution to the interaction from the effects stemming from the local symmetry around the lanthanide ion, so-named long range effects, and the rigidity of system, respectively. Using the calculated parameters $\Omega_{\mathrm{i}}$, the strength of the electric dipole lines $\mathrm{S}_{\mathrm{ED}}$ and the probabilities of spontaneous emission $\mathrm{A}_{\mathrm{ED}}$ for all the observed optical transitions $\mathrm{Sm}^{3+}$ in $\mathbf{4}$ was made. The data for the most significant luminescent transitions summarized in Table 1 include the calculated $A_{E D}$ values for the ${ }^{4} G_{5 / 2} \rightarrow X$ transitions in complex 4 in the THF solution, observed in the visible and NIR spectral regions, as well as the $\mathrm{A}_{\mathrm{MD}}$ calculations based on the literature values for the strength of $S_{M D}$ magnetic dipole lines in the luminescence spectrum [41,42]. The total luminescence probability $A_{\Sigma}=A_{E D}+A_{M D}$ and the branching ratio $\beta$ for a given state are also provided.

Table 1. Parameters of luminescence of samarium complex 4 in THF solution.

\begin{tabular}{|c|c|c|c|c|c|c|c|}
\hline${ }^{4} \mathrm{G}_{5 / 2} \rightarrow{ }^{2 S+1} \mathrm{~L}_{\mathrm{J}}$ & $\lambda(\mathrm{nm})$ & $S_{E D}\left(\times 10^{-23} \mathrm{~cm}^{2}\right)$ & $A_{E D}\left(s^{-1}\right)$ & $S_{M D}\left(\times 10^{-23} \mathrm{~cm}^{2}\right)$ & $A_{M D}\left(s^{-1}\right)$ & $A_{\Sigma}\left(s^{-1}\right)$ & $\beta(\%)$ \\
\hline${ }^{6} \mathrm{~F}_{5 / 2}$ & 958 & 16.3 & 5.56 & 6.62 & 2.48 & 8.04 & 5.65 \\
\hline${ }^{6} \mathrm{~F}_{3 / 2}$ & 933 & 2.2 & 0.81 & 8.46 & 3.44 & 4.25 & 2.99 \\
\hline${ }^{6} \mathrm{H}_{13 / 2}$ & 795 & 4.5 & 2.69 & 0 & 0 & 2.69 & 1.89 \\
\hline${ }^{6} \mathrm{H}_{11 / 2}$ & 706 & 14.4 & 12.28 & 0 & 0 & 12.28 & 8.63 \\
\hline${ }^{6} \mathrm{H}_{9 / 2}$ & 650 & 37.2 & 40.73 & 0 & 0 & 40.73 & 28.63 \\
\hline${ }^{6} \mathrm{H}_{7 / 2}$ & 605 & 36.2 & 49.04 & 5.81 & 8.66 & 57.70 & 40.56 \\
\hline${ }^{6} \mathrm{H}_{5 / 2}$ & 568 & 1.62 & 2.65 & 5.73 & 10.32 & 12.97 & 9.12 \\
\hline
\end{tabular}

The total luminescence probability $A_{\Sigma}$ consists of two parts: the $A_{E D}$, the electrodipole component calculated by the standard method using the obtained $\Omega_{\mathrm{i}}$ values, and $\mathrm{A}_{\mathrm{MD}}$, the magnetic-dipole component, with a non-zero value for a number of transitions, taking into account the selection rules typical for this class of compounds [43]. It should be noted that the probability values of magnetic dipole transitions do not depend on the matrix in $\mathrm{Ln}^{3+}$ compounds and can be taken from the literature. The values of the obtained intensity parameters $\Omega_{2}-\Omega_{6}$ allow the estimation of the total probability of all radiative transitions from the excited ${ }^{4} \mathrm{G}_{5 / 2}$ state as $\mathrm{A}_{\text {rad }} \approx 142 \mathrm{~s}^{-1}$ and the lifetime of this state as $\tau_{\text {calc }} \approx 7.03 \mathrm{~ms}$. Such values for the radiative lifetime of the excited state exceed by about two orders of magnitude of the experimental values of the lifetime, obtained from the excitation decay exponential curve, obtained by the method of time-resolved spectroscopy. The significant discrepancy between the experimental and calculated values of $\tau$ is apparently explained by the fact that the calculation method does not make it possible to take into account the nonradiative transitions [40-42].

\subsection{Luminescence}

It was previously shown that in the fluorescent spectra (PL) of non-fluorinated benzothiazolyl lanthanide complexes there are two bands: at around $430 \mathrm{~nm}$ (enol) and $520 \mathrm{~nm}$ (keto) forms [34]. Upon photo excitation with $\lambda_{\text {exc }} 380-395 \mathrm{~nm}$, the fluorinated complexes 1-2 and benzothiazole $\mathrm{H}\left(\mathrm{SON}^{\mathrm{F}}\right)$ in THF or MeCN solutions exhibit only one broadened band in the region $460-480 \mathrm{~nm}$, corresponding to the enol form, which, apparently, is more preferable in this case (Figure 7). The relative fluorescence quantum yield of the obtained compounds is close to $100 \%$. This is significantly higher than that of non-fluorinated analogues [34].

The $\mathrm{T}_{1}$ level of the $\mathrm{SON}^{\mathrm{F}}$ ligand equal to $20,060 \mathrm{~cm}^{-1}$ was determined by the low-temperature photoluminescence spectrum of the gadolinium complex (Figure S4), by the position of the short-wave edge of the phosphorescence band, which is taken as the value corresponding to the $0-0$ transition $[44,45]$. This position of the triplet level suggests that ligands can be an effective sensitizer for the PL of $\mathrm{Ln}^{3+}$ ions emitting in the visible region. According to this assumption, it has been found that the PL spectra of the $\mathrm{Sm}$ and $\mathrm{Eu}$ complexes, along with the bands of $\mathrm{SON}^{\mathrm{F}}$ ligands, display the bands of the respective metal (Figure 8).

The spectrum of complex 4 in the visible region both in the solid state and in solution contains metal-centered emission bands characteristic for $\mathrm{Sm}^{3+}$, corresponding to transitions ${ }^{4} \mathrm{G}_{5 / 2} \rightarrow{ }^{6} \mathrm{H}_{5 / 2}$, 
${ }^{6} \mathrm{H}_{7 / 2},{ }^{6} \mathrm{H}_{9 / 2}$, and ${ }^{6} \mathrm{H}_{11 / 2}$. As well the luminescence in the NIR region is caused by ${ }^{4} \mathrm{G}_{5 / 2} \rightarrow{ }^{6} \mathrm{H}_{11 / 2},{ }^{6} \mathrm{H}_{13 / 2}$, ${ }^{6} \mathrm{~F}_{1 / 2},{ }^{6} \mathrm{~F}_{3 / 2},{ }^{6} \mathrm{H}_{15 / 2},{ }^{6} \mathrm{~F}_{5 / 2}$, and ${ }^{6} \mathrm{~F}_{11 / 2}$ transition and Stark splitting (Figure 9). The measurement of the ${ }^{4} \mathrm{G}_{5 / 2}$ excited state lifetime ( $\tau_{\exp } \approx 15.5 \mu \mathrm{s}$ ) for complex 4 allowed the calculation of the PL quantum efficiency $\eta=A_{\text {rad }} /\left(A_{\text {rad }}+A_{\text {nonrad }}\right)=\tau_{\text {exp }} / \tau_{\text {calc }}(\times 100 \%)$ at room temperature, taking into account the above theoretically estimated radiative relaxation time $\left(\tau_{\text {calc }} \approx 7.03 \mathrm{~ms}\right)$. The found value of $\eta \approx 0.22 \%$ corresponds to this parameter estimated for other $\mathrm{Sm}^{3+}$ compounds $[40,46]$ and can be considered evidence of the moderate luminescence ability of this class of compounds.

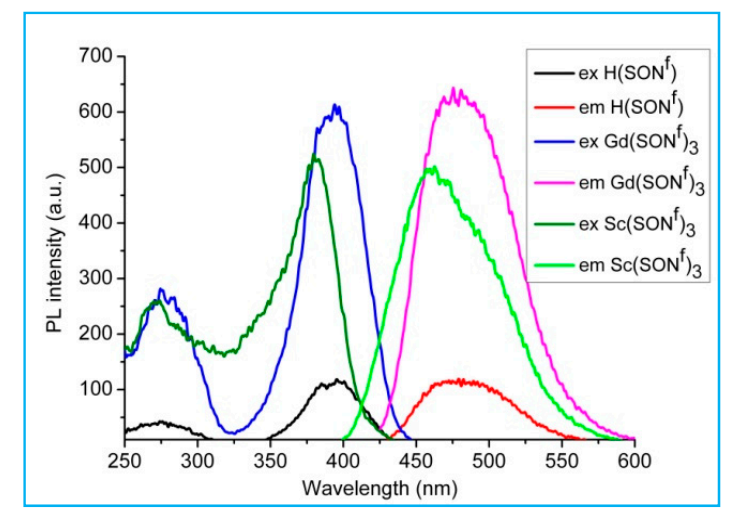

Figure 7. PL excitation and PL spectra of (benzothiazolyl)phenole $\mathrm{H}\left(\mathrm{SON}^{\mathrm{F}}\right)$ and complexes 1 and 2 $\left(\lambda_{\mathrm{exc}}=395 \mathrm{~nm}\right)$ in a THF solution $\left(10^{-5} \mathrm{M}\right)$.

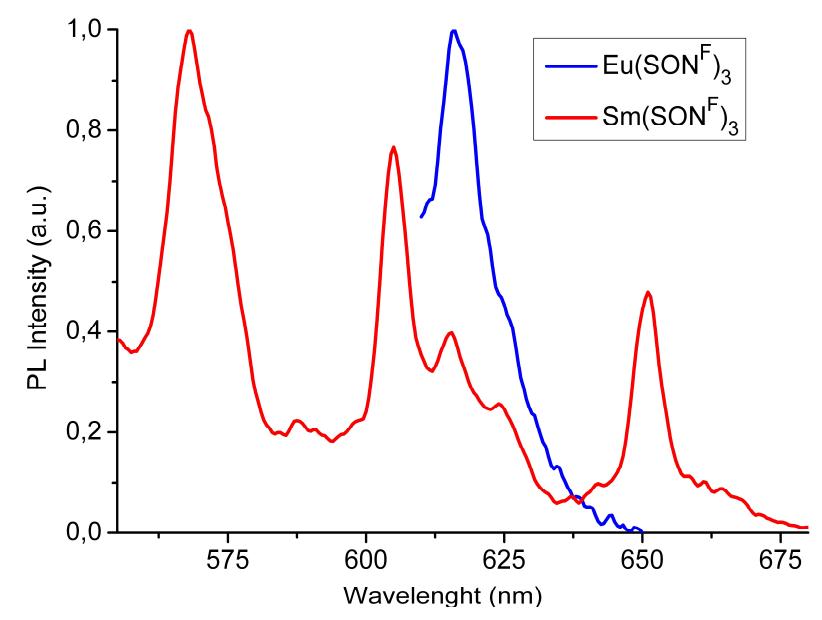

Figure 8. Normalized PL spectra of the complexes 4 and $5\left(\lambda_{\text {exc }}=395 \mathrm{~nm}\right)$ in a THF solution $\left(10^{-4} \mathrm{M}\right)$.

The europium complex 5, in contrast to the non-emissive non-fluorinated analog, revealed a weak metal-centered luminescence in a THF solution at $616 \mathrm{~nm}$, corresponding to the ${ }^{5} \mathrm{D}_{0} \rightarrow{ }^{7} \mathrm{~F}_{2}$ transition (Figure 8). This observation is consistent with the known fact of quenching the luminescence of europium by phenol-substituted ligands due to the appearance in the complex of LMCT states and the low reduction potential of the $\mathrm{Eu}$ (III) ion [47]. The complexes $\mathrm{Nd}, \mathrm{Er}$, and $\mathrm{Yb}$ showed luminescence in the NIR region upon $405 \mathrm{~nm}$ laser excitation (Figure 9).

The triplet level of the ligands $\left(20,600 \mathrm{~cm}^{-1}\right)$ matches well the energy of the resonant level ${ }^{4} \mathrm{G}_{5 / 2}$ of the $\mathrm{Nd}^{3+}$ ion $\left(17135 \mathrm{~cm}^{-1}\right)$, which provides the effective transfer of the excitation energy from the ligand to the metal and, as a result, leads to a high intensity of metal-centered emission. Effective sensitization can also be due to the short non-radiative relaxation time from the excited ${ }^{4} \mathrm{G}_{5 / 2}$ state to the emission state ${ }^{4} \mathrm{~F}_{3 / 2}$ of the neodymium ion, which follows from the analysis of time-resolved spectroscopy data. It should be noted that the intensity of metal-centered emission in the PL spectra of the solid samples of complex 3 substantially exceeds the similar characteristic of that of non-fluoroinated analogues [21]. 

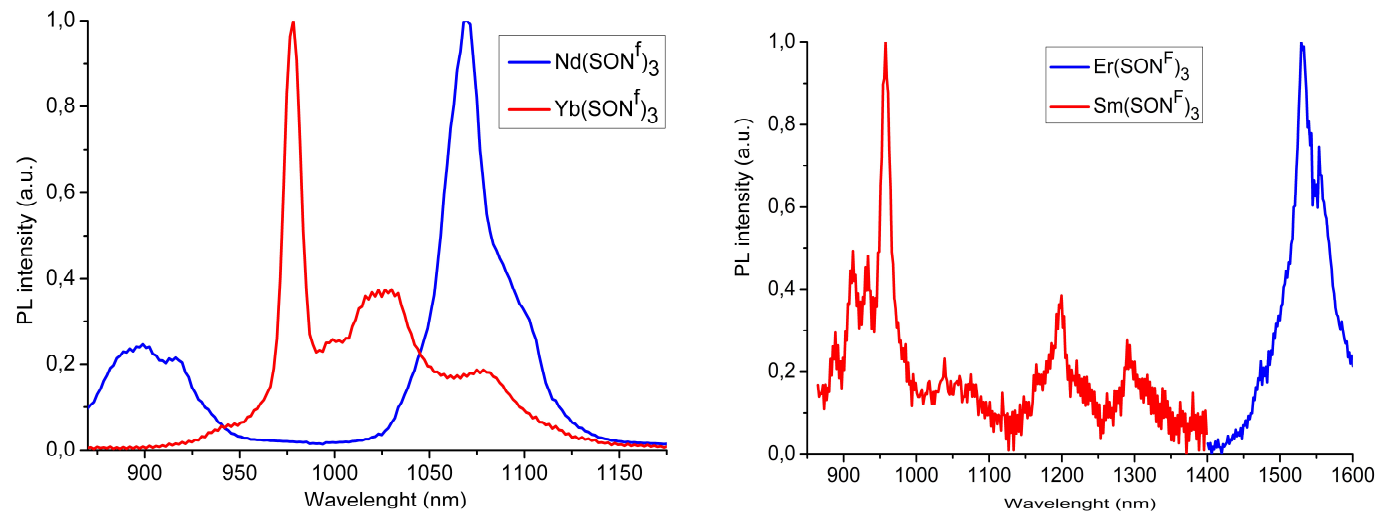

Figure 9. Normalized PL spectra of the solid samples of the complexes $3,4,7$, and 8 ( $\left.\lambda_{\mathrm{exc}}=405 \mathrm{~nm}\right)$.

The difference between the energies of the triplet level of the ligand and the energy of the ${ }^{4} \mathrm{~S}_{3 / 2}$ level of erbium $\left(2200 \mathrm{~cm}^{-1}\right)$ does not quite match the optimal value of the energy gap $\left(2500-3500 \mathrm{~cm}^{-1}\right)$ necessary for effective sensitization. As a result, the Er complex 7 displayed only weak metal-centered emission at $1540 \mathrm{~nm}$, corresponding to the ${ }^{4} \mathrm{I}_{13 / 2} \rightarrow{ }^{4} \mathrm{I}_{15 / 2}$ transition (Figure 9). In the case of the $\mathrm{Yb}$ complex 8, such a way of energy transfer is impossible because of the too large energy gap between the triplet level of $\mathrm{SON}^{\mathrm{F}}$ and the ${ }^{2} \mathrm{~F}_{5 / 2}$ resonant state of the $\mathrm{Yb}$ ion $\left(10,330 \mathrm{~cm}^{-1}\right)$. However, complex 8 gives a characteristic band of the ${ }^{2} \mathrm{~F}_{5 / 2} \rightarrow{ }^{2} \mathrm{~F}_{7 / 2}$ transition of the $\mathrm{Yb}^{3+}$ ion at $978 \mathrm{~nm}$ of moderate intensity, accompanied by Stark splitting bands in the region 1000-1100 $\mathrm{nm}$. The sensitization of metal-centered $\mathrm{PL}$ in the $\mathrm{Yb}$ complex probably occurs due to the realization of a redox mechanism involving the photoinduced intramolecular electron transfer, as it was previously suggested for the non-fluorinated analogue [48]. The Ho complex 6 exhibits only ligand luminescence.

The kinetic PL measurements of complexes 3, 4, and 7 revealed that the $\mathrm{Nd}, \mathrm{Sm}$, and Er derivatives show monoexponential decay curves of the metal-centered emissions, with lifetimes of 1.07, 15.5, and $2 \mu \mathrm{s}$, respectively. For the $\mathrm{Yb}$ complex 8, the exponent function is not fitted well and the lifetime varies in the range 5-7 $\mu$ s (Figure S5). The lifetimes of the NIR PL of the obtained complexes are essentially shorter than those of compounds of respective lanthanides with other perfluorinated ligands (30-700 $\mu \mathrm{s})[49,50]$. Apparently, this behavior is due to the presence of strong quenchers (coordinated DME molecules) in these complexes. As is pointed out above, removing from the complex the anionic or neutral ligands containing quenching $\mathrm{C}-\mathrm{H}$ groups leads to an increase of the luminescence efficiency [51-53].

\subsection{DFT Modeling}

To trace the difference in the electronic structure between fluorinated and non-fluorinated complexes, which can reflect on their luminescent characteristics, the DFT calculations of the scandium complex $\mathbf{2}$ were performed. The optimized geometry of $\mathbf{2}$ is given in Figure S6. The calculated parameters coincide with experimentally found values. The HOMO orbital is located on two ligands coordinated monodentately with the central ion. The HOMO of 2 represents an almost pure ligand orbital with a metal contribution of less than $1 \%$, while the LUMO orbital is the almost pure orbital of the third ligand (bidentately bound) with the inclusion of a small contribution of the scandium atom (Figure 10). The HOMO-LUMO electronic transition can be considered, therefore, as an interligand charge transfer with a contribution of LMCT.

As in the case of similar complexes of zinc [25], the fluorination of ligands in complex 2 leads to a decrease in the energies of the frontier orbitals. However, in the scandium complex with the fluorinated ligand, a more significant decrease in HOMO and a less significant decrease in the LUMO in comparison with the non-fluorinated analogue occurs [20]. This can probably be explained by the different coordination of the ligands: in complex 2, two ligands are coordinated monodentately and the third one bidentately, while in the non-fluoronated counterpart all three bensothiasolyl ligands 
are bound with Sc bidentately. Since the electron density of HOMO in complex 2 is located on a monodentately bound ligand, which is absent in the non-fluorinated compound, a difference arises in the energy of HOMO. The bidentately coordinated ligands, on which LUMO is mainly focused, the energy of LUMO in both complexes therefore decreases insignificantly. The absorption spectrum and photoluminescence of $\mathbf{2}$ is slightly red-shifted relative to the non-fluorinated analogue (Figure S6).

HOMO

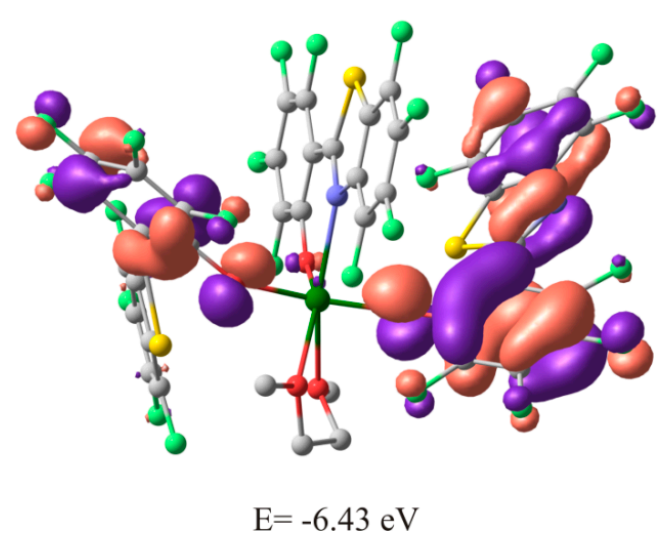

LUMO

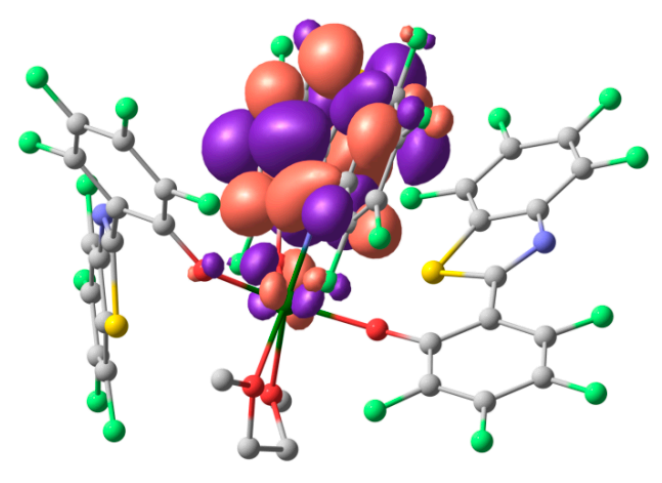

$\mathrm{E}=-2.96 \mathrm{eV}$

Figure 10. The shapes of HOMO and LUMO for complex 2 calculated by the DFT B3LYP/def2svp method (cutoff $\left.=0.03 \mathrm{e} / \AA^{3}\right)$.

\section{Materials and Methods}

\subsection{Characterization and Measurements}

All manipulations were carried out under vacuum using standard Schlenk techniques. Solvents (DME and THF) were purified by distillation from sodium/benzophenone ketyl. The lanthanide complexes $\mathrm{Ln}\left[\mathrm{N}\left(\mathrm{SiMe}_{3}\right)_{2}\right]_{3}$ were synthesized according to the procedure published elsewhere [54]. 2-(3,4,5,6-Tetrafluoro-2-hydroxyphenyl)-4,5,6,7-tetrafluorobenzothiazole $\left(\mathrm{H}\left(\mathrm{SON}^{\mathrm{F}}\right)\right)$ was synthesized by a multistep method, described in publications [25]. The molecular structure of the compound was established in this work. The C, H, and N elemental analyses were performed at the Elementar Vario EL cube Analyzer (Elementar Analysensysteme GmbH, Langenselbold, Germany). The lanthanide content was analyzed by complexometric titration. IR spectra were obtained on a Perkin Elmer 577 spectrometer (Waltham, MA, USA) as a Nujol mull on KBr plates in the $450-4000 \mathrm{~cm}^{-1}$ region. Samples were prepared as a Nujol mull on $\mathrm{KBr}$ plates. Emission spectra were registered from 300 to $700 \mathrm{~nm}$ on a fluorescent spectrometer Perkin Elmer LS-55. Relative PL quantum yields of the synthesized complexes in $\mathrm{CH}_{3} \mathrm{CN}$ were measured at ambient conditions with an excitation wavelength of $390 \mathrm{~nm}$, and the values were calculated using Rhodamine 6G in ethanol $(\Phi=0.95)$ as standard [55], according to the known procedure [56]. A Perkin Elmer Lambda 900 UV-vis absorption spectrophotometer was used to record absorption spectra. Registration of absorption and emission spectra was performed in a $1 \mathrm{~cm}$ fluorescent quartz cuvette. UV-Vis absorption spectra of samarium complex was recorded on a Shimadzu UV-3600 from 200 to $1600 \mathrm{~nm} .{ }^{19} \mathrm{~F}-\mathrm{NMR}$ spectra were recorded at $376 \mathrm{MHz}$ in d8-THF by using an Agilent DD2 400 spectrometer (Agilent Technologies, Santa Clara, CA, USA). Deuterated solvent d8-THF was used as received from Aldrich (St. Louis, MO, USA).

\subsection{Synthesis Details}

\subsubsection{Synthesis of $\mathrm{Gd}\left(\mathrm{SON}^{\mathrm{F}}\right)_{3}(\mathrm{DME})(\mathbf{1})$}

A solution of 2-(3,4,5,6-tetrafluoro-2-hydroxyphenyl)-4,5,6,7-tetrafluorobenzothiazole (119 mg, $0.321 \mathrm{mmol})$ in DME $(10 \mathrm{~mL})$ was added to a solution of $\mathrm{Gd}\left[\mathrm{N}\left(\mathrm{SiMe}_{3}\right)_{2}\right]_{3}(68 \mathrm{mg}, 0.107 \mathrm{mmol})$ in DME (5 mL). The reaction mixture was stirred for $30 \mathrm{~min}$ at room temperature. The solution was 
concentrated to $2 \mathrm{~mL}$. The light-yellow precipitate of complex 1 had been landed from hexane, separated by decantation, washed with cold hexane, and dried in vacuum, yielding $100 \mathrm{mg}(65 \%)$. Anal. Calcd. (\%) for $\mathrm{C}_{43} \mathrm{H}_{10} \mathrm{~F}_{24} \mathrm{GdN}_{3} \mathrm{O}_{5} \mathrm{~S}_{3}$ (1357.96) C, 38.03; $\mathrm{H}, 0.74 ; \mathrm{Gd}, 11.58 ; \mathrm{N}, 3.09 ; \mathrm{S}, 7.08$. Found (\%) C, 38.06; $\mathrm{H}, 0.75 ; \mathrm{Gd}, 11.61 ; \mathrm{N}, 3.04 ; \mathrm{S}, 7.11$. IR (KBr, $\left.v, \mathrm{~cm}^{-1}\right): 1650(\mathrm{~m}), 1581(\mathrm{w}), 1256(\mathrm{~s}), 1184(\mathrm{~m}), 1099(\mathrm{~m})$, $1052(\mathrm{~m}), 995(\mathrm{~s}), 886(\mathrm{w}), 846(\mathrm{~m}), 817(\mathrm{w}), 751(\mathrm{~m}), 621(\mathrm{w}), 600(\mathrm{w}), 523(\mathrm{w}), 497(\mathrm{w})$.

The complexes of Sc, Nd, Sm, Eu, Ho, Er, and $\mathrm{Yb}$ were obtained in a similar manner.

\subsubsection{Synthesis of $\mathrm{Sc}\left(\mathrm{SON}^{\mathrm{F}}\right)_{3}(\mathrm{DME})$ (2)}

A total of $46 \mathrm{mg}(75 \%)$ of 2 was prepared from $55 \mathrm{mg}(0.148 \mathrm{mmol})$ of $\mathrm{H}\left(\mathrm{SON}^{\mathrm{F}}\right)$ and $26 \mathrm{mg}(0.049$ mmol) of $\mathrm{Sc}\left[\mathrm{N}\left(\mathrm{SiMe}_{3}\right)_{2}\right]_{3}$. Anal. Calcd. (\%) for $\mathrm{C}_{43} \mathrm{H}_{10} \mathrm{~F}_{24} \mathrm{~N}_{3} \mathrm{O}_{5} \mathrm{~S}_{3} \mathrm{Sc}$ (1245.68) C, 41.46; $\mathrm{H}, 0.81 ; \mathrm{N}$, 3.37; S, 7.72; Sc, 3.61. Found (\%) C, 41.38; H, 0.75; N, 3.34; S, 7.79; Sc, 3.54. ${ }^{19} \mathrm{~F}-\mathrm{NMR}(376 \mathrm{MHz}$, THF-d8, $\left.20{ }^{\circ} \mathrm{C}\right), \delta \mathrm{F}:-140.5(\mathrm{~m}),-141.9(\mathrm{~m}),-149.0(\mathrm{~m}),-157.1(\mathrm{~m}),-160.4(\mathrm{~m}),-161.9(\mathrm{~m}),-163.5(\mathrm{~m})$, $-179.0(\mathrm{~m})$.

The qualitative crystals suitable for X-ray analysis were obtained by recrystallization of the product from a mixture of DME-hexane.

\subsubsection{Synthesis of $\mathrm{Nd}\left(\mathrm{SON}^{\mathrm{F}}\right)_{3}(\mathrm{DME})(3)$}

Complex 3 was prepared from $94 \mathrm{mg}(0.253 \mathrm{mmol})$ of $\mathrm{H}\left(\mathrm{SON}^{\mathrm{F}}\right)$ and $53 \mathrm{mg}(0.085 \mathrm{mmol})$ of $\mathrm{Nd}\left[\mathrm{N}\left(\mathrm{SiMe}_{3}\right)_{2}\right]_{3}$. Yield: $91 \mathrm{mg}(75 \%)$. Anal. Calcd. (\%) for $\mathrm{C}_{43} \mathrm{H}_{10} \mathrm{~F}_{24} \mathrm{~N}_{3} \mathrm{NdO}_{5} \mathrm{~S}_{3}(1344.95) \mathrm{C}, 38.40 ; \mathrm{H}$, $0.75 ; \mathrm{N}, 3.12 ; \mathrm{Nd}, 10.72 ; \mathrm{S}, 7.15$. Found (\%) C, 38.39; H, 0.77; N, 3.09; Nd, 10.69; S, 7.12.

\subsubsection{Synthesis of $\mathrm{Sm}\left(\mathrm{SON}^{\mathrm{F}}\right)_{3}(\mathrm{DME})(4)$}

A total of $85 \mathrm{mg}(76 \%)$ of 4 was obtained from $92 \mathrm{mg}(0.248 \mathrm{mmol})$ of $\mathrm{H}\left(\mathrm{SON}^{\mathrm{F}}\right)$ and $52 \mathrm{mg}$ (0.082 mmol)of Sm[N(SiMe $\left.)_{2}\right]_{3}$. Anal. Calcd. (\%) for $\mathrm{C}_{43} \mathrm{H}_{10} \mathrm{~F}_{24} \mathrm{~N}_{3} \mathrm{O}_{5} \mathrm{~S}_{3} \mathrm{Sm}$ (1351.07) C, 38.23; H, 0.75; $\mathrm{N}, 3.11 ; \mathrm{S}, 7.12$; Sm, 11.13. Found (\%) C, 38.20; H, 0.79; N, 3.05; S, 7.19; Sm, 11.11.

\subsubsection{Synthesis of $\mathrm{Eu}\left(\mathrm{SON}^{\mathrm{F}}\right)_{3}(\mathrm{DME})(5)$}

Complex $4(83 \mathrm{mg}, 73 \%)$ was isolated from the reaction of $93 \mathrm{mg}(0.251 \mathrm{mmol})$ of $\mathrm{H}\left(\mathrm{SON}^{\mathrm{F}}\right)$ with $\mathrm{Sm}\left[\mathrm{N}\left(\mathrm{SiMe}_{3}\right)_{2}\right]_{3}(53 \mathrm{mg}, 0.084 \mathrm{mmol})$. Anal. Calcd. (\%) for $\mathrm{C}_{43} \mathrm{H}_{10} \mathrm{EuF}_{24} \mathrm{~N}_{3} \mathrm{O}_{5} \mathrm{~S}_{3}(1352.67) \mathrm{C}, 38.18 ; \mathrm{H}$, $0.75 ; \mathrm{Eu}, 11.23 ; \mathrm{N}, 3.11 ; \mathrm{S}, 7.11$. Found (\%) C, 38.19; H, 0.76; Eu, 11.27; N, 3.08; S, 7.16.

\subsubsection{Synthesis of $\mathrm{Ho}\left(\mathrm{SON}^{\mathrm{F}}\right)_{3}(\mathrm{DME})(6)$}

A total of $86 \mathrm{mg}(0.232 \mathrm{mmol})$ of $\mathrm{H}\left(\mathrm{SON}^{\mathrm{F}}\right)$ and $50 \mathrm{mg}(0.077 \mathrm{mmol})$ of $\mathrm{Ho}\left[\mathrm{N}\left(\mathrm{SiMe}_{3}\right)_{2}\right]_{3}$ yielded $74 \mathrm{mg}(70 \%)$ of 6 . Anal. Calcd. (\%) for $\mathrm{C}_{43} \mathrm{H}_{10} \mathrm{~F}_{24} \mathrm{HoN}_{3} \mathrm{O}_{5} \mathrm{~S}_{3}$ (1365.64) C, 37.82; H, 0.74; Ho, 12.08; N, $3.08 ; \mathrm{S}, 7.04$. Found (\%) C, 37.83; H, 0.69; Ho, $12.05 ; \mathrm{N}, 3.02 ; \mathrm{S}, 7.07$.

\subsubsection{Synthesis of $\operatorname{Er}\left(\mathrm{SON}^{\mathrm{F}}\right)_{3}(\mathrm{DME})(7)$}

Complex 7 (92 mg, 75\%) was obtained from $\mathrm{H}\left(\mathrm{SON}^{\mathrm{F}}\right)(100 \mathrm{mg}, 0.269 \mathrm{mmol})$ and $\operatorname{Er}\left[\mathrm{N}\left(\mathrm{SiMe}_{3}\right)_{2}\right]_{3}$ (58 mg, 0.089 mmol). Anal. Calcd. (\%) for $\mathrm{C}_{43} \mathrm{H}_{10} \mathrm{ErF}_{24} \mathrm{~N}_{3} \mathrm{O}_{5} \mathrm{~S}_{3}$ (1367.97) C, 37.75; H, 0.74; Er, 12.23; N, 3.07; S, 7.03. Found (\%) C, 37.79; H, 0.76; Er, 12.21; N, 3.02; S, 7.05.

The crystals suitable for X-ray analysis were obtained by recrystallization of the product from the methanol.

\subsubsection{Synthesis of $\mathrm{Yb}\left(\mathrm{SON}^{\mathrm{F}}\right)_{3}(\mathrm{DME})(8)$}

From $107 \mathrm{mg}(0.288 \mathrm{mmol})$ of $\mathrm{H}\left(\mathrm{SON}^{\mathrm{F}}\right)$ and $63 \mathrm{mg}(0.096 \mathrm{mmol})$ of $\mathrm{Yb}\left[\mathrm{N}\left(\mathrm{SiMe}_{3}\right)_{2}\right]_{3} 102 \mathrm{mg}(77 \%)$ of 8 was prepared. Anal. Calcd. (\%) for $\mathrm{C}_{43} \mathrm{H}_{10} \mathrm{~F}_{24} \mathrm{~N}_{3} \mathrm{O}_{5} \mathrm{~S}_{3} \mathrm{Yb}$ (1373.76) C, 37.60; H, 0.73; N, 3.06; S, 7.00; $\mathrm{Yb}, 12.60$. Found (\%) C, 37.57; H, 0.75; N, 2.97; S, 7.03; Yb, 12.58 .

The IR spectra of complexes 2-8 are identical to that of $\mathbf{1}$. 


\subsection{X-Ray Single-Crystal Diffraction Analysis of $H\left(S O N^{F}\right), \mathbf{2}$, and $\mathbf{7}$}

The X-ray diffraction data were collected on an Agilent Xcalibur E (2) and a Bruker D8 Quest $\left(\mathrm{H}\left(\mathrm{SON}^{\mathrm{F}}\right)\right.$ and 7$)$ diffractometers $\left(\mathrm{MoK}_{\alpha}\right.$ radiation, $\omega$-scan technique, $\lambda=0.71073 \AA$, Bruker $\mathrm{AXS}$, Madison, WI, USA). The intensity data were integrated by CrysAlisPro [57] for 2 and by SAINT [58] for $\mathrm{H}\left(\mathrm{SON}^{\mathrm{F}}\right)$ and 7 . The structures $\mathrm{H}\left(\mathrm{SON}^{\mathrm{F}}\right), \mathbf{2}$, and $\mathbf{7}$ were solved by dual method [59] and were refined on $\mathrm{F}^{2}{ }_{h k l}$ using the SHELXL package [60]. All non-hydrogen atoms were refined anisotropically. All hydrogen atoms were placed in calculated positions and were refined in the riding model. The $\mathrm{H}(1)$ in $\mathrm{H}\left(\mathrm{SON}^{\mathrm{F}}\right)$ was found from the Fourier difference synthesis of electron density and refined isotropically. SCALE3 ABSPACK [61] for 2 and SADABS [62] for $\mathrm{H}\left(\mathrm{SON}^{\mathrm{F}}\right)$ and $\mathbf{7}$ were used to perform area-detector scaling and absorption corrections. The main crystallographic data and structure refinement details for $\mathrm{H}\left(\mathrm{SON}^{\mathrm{F}}\right)$, 2, and 7 are presented in Table 2. Cambridge Crystallographic Data Centre (CCDC) $1,883,260\left(\mathrm{H}\left(\mathrm{SON}^{\mathrm{F}}\right)\right), 1,883,261(2)$, and 1,883,259 (7) contain the supplementary crystallographic data for this paper. These data can be obtained free of charge www.ccdc.cam.ac.uk/structures/from the Cambridge Crystallographic Data Centre.

Table 2. X-ray data collection and refinement parameters for $\mathrm{H}\left(\mathrm{SON}^{\mathrm{F}}\right), \mathbf{2}$, and 7 .

\begin{tabular}{|c|c|c|c|}
\hline Complex & $\mathrm{H}\left(\mathrm{SON}^{\mathrm{F}}\right)$ & 2 & 7 \\
\hline Empirical formula & $\mathrm{C}_{13} \mathrm{HF}_{8} \mathrm{NOS}$ & $\mathrm{C}_{43} \mathrm{H}_{10} \mathrm{~F}_{24} \mathrm{~N}_{3} \mathrm{O}_{5} \mathrm{~S}_{3} \mathrm{Sc}$ & $\mathrm{C}_{43} \mathrm{H}_{16} \mathrm{~F}_{24} \mathrm{~N}_{3} \mathrm{O}_{7} \mathrm{~S}_{3} \mathrm{Er}$ \\
\hline Formula weight & 371.21 & 1245.68 & 1406.03 \\
\hline $\mathrm{T}(\mathrm{K})$ & $100(2)$ & $100(2)$ & $100(2)$ \\
\hline Crystal system & Monoclinic & Triclinic & Triclinic \\
\hline Space group & $\mathrm{Cc}$ & P-1 & P-1 \\
\hline \multicolumn{4}{|c|}{ Unit cell dimensions } \\
\hline a $(\AA)$ & $9.4594(3)$ & $11.1909(5)$ & $12.0137(7)$ \\
\hline $\mathrm{b}(\AA)$ & $12.5014(4)$ & $14.0354(6)$ & $12.1785(7)$ \\
\hline$c(\AA)$ & $20.1166(6)$ & $15.0479(7)$ & 16.3474(9) \\
\hline$\alpha\left({ }^{\circ}\right)$ & 90 & $99.295(4)$ & $84.9199(15)$ \\
\hline$\beta\left(^{\circ}\right)$ & $93.6280(10)$ & $109.580(4)$ & $88.0365(14)$ \\
\hline$\gamma\left(\left(^{\circ}\right)\right.$ & 90 & $94.136(4)$ & $72.0830(13)$ \\
\hline $\mathrm{V}\left(\AA^{3}\right)$ & 2374.14(13) & 2177.28(19) & $2266.8(2)$ \\
\hline $\mathrm{Z}$ & 8 & 2 & 2 \\
\hline$D_{\text {calc. }}\left(\mathrm{g} \cdot \mathrm{cm}^{-3}\right)$ & 2.077 & 1.900 & 2.060 \\
\hline Absorption coefficient, $\mu\left(\mathrm{mm}^{-1}\right)$ & 0.386 & 0.470 & 2.146 \\
\hline $\mathrm{F}(000)$ & 1456 & 1228 & 1366 \\
\hline Crystal size $\left(\mathrm{mm}^{3}\right)$ & $0.50 \times 0.50 \times 0.50$ & $0.30 \times 0.25 \times 0.03$ & $0.16 \times 0.13 \times 0.04$ \\
\hline Range for data collection, $\theta\left(^{\circ}\right)$ & $2.029-32.000$ & $2.931-25.000$ & $2.502-30.034$ \\
\hline \multirow{3}{*}{ Limiting indices } & $-14 \leq \mathrm{h} \leq 14$ & $-13 \leq h \leq 13$ & $-16 \leq h \leq 16$ \\
\hline & $-18 \leq \mathrm{k} \leq 18$ & $-16 \leq \mathrm{k} \leq 16$ & $-17 \leq \mathrm{k} \leq 17$ \\
\hline & $-29 \leq 1 \leq 29$ & $-17 \leq 1 \leq 17$ & $-23 \leq 1 \leq 23$ \\
\hline Reflections collected/unique & $17441 / 8202$ & $21419 / 7655$ & $32615 / 13211$ \\
\hline $\mathrm{R}_{\text {(int) }}$ & 0.0199 & 0.0497 & 0.0504 \\
\hline Completeness (to $\theta$ ) & $99.9 \%(25.242)$ & $99.6 \%(25.000)$ & $99.8 \%(25.242)$ \\
\hline Data/restraints/parameters & $8202 / 184 / 591$ & $7655 / 0 / 714$ & $13211 / 13 / 750$ \\
\hline Goodness-of-fit (GOF) on $\mathrm{F}^{2}$ & 1.024 & 1.020 & 1.031 \\
\hline Final $R$ indices $[\mathrm{I}>2 \sigma(\mathrm{I})]$ & $\begin{array}{l}\mathrm{R}_{1}=0.0283 \\
\mathrm{wR}_{2}=0.0755\end{array}$ & $\begin{array}{l}\mathrm{R}_{1}=0.0716 \\
\mathrm{w} \mathrm{R}_{2}=0.1652\end{array}$ & $\begin{array}{l}\mathrm{R}_{1}=0.0387 \\
\mathrm{w} \mathrm{R}_{2}=0.0708\end{array}$ \\
\hline $\mathrm{R}$ indices (all data) & $\begin{array}{l}\mathrm{R}_{1}=0.0305 \\
\mathrm{wR}_{2}=0.0767\end{array}$ & $\begin{array}{l}\mathrm{R}_{1}=0.1151 \\
\mathrm{w} \mathrm{R}_{2}=0.1827\end{array}$ & $\begin{array}{l}\mathrm{R}_{1}=0.0555 \\
w \mathrm{R}_{2}=0.0750\end{array}$ \\
\hline Largest diff. peak/hole $\left(\mathrm{e} \AA^{-3}\right)$ & $0.478 /-0.349$ & $1.109 /-0.451$ & $1.859 /-1.262$ \\
\hline
\end{tabular}

\subsection{Computational Details}

Density functional theory (DFT) calculations were performed using the Gaussian 09 program package [63]. A full geometry optimization of complex 2 was accomplished at the B3LYP/def2svp 
level, with subsequent checking for the stability of the DFT wave function. Structural visualizations in Figure 10 were produced with the program suite ChemCraft [64].

\subsection{Time-Resolved Spectroscopy}

The PL decay times were measured under pulsed excitation with a Spectra-Physics optical parametric oscillator at 430 and $474 \mathrm{~nm}$ (Spectra-Physics, Santa Clara, CA, USA). The duration of the excitation pulse was $10 \mathrm{~ns}$. The PL signal in the $450-800 \mathrm{~nm}$ range was dispersed using a grating spectrometer Acton-2300 (Teledyne Princeton Instruments, Trenton, NJ, USA) and detected using a Si-based photomultiplier tube (PMT) (Hamamatsu photonics, Hamamatsu, Japan) and a LeCroy digital oscilloscope (Teledyne LeCroy, Chestnut Ridge, NY, USA).

\section{Conclusions}

A set of rare-earth metals complexes with perfluorinated 2-(2-hydroxyphenyl)benzothiazolate ligands were obtained and structurally characterized. All the compounds (except Sc and Gd) upon excitation by UV light displayed a metal-centered PL of moderate intensity. The emission spectra corresponded to respective $\mathrm{Ln}^{3+}$ ions. The complexes of Sc and Gd exhibited only the PL of the ligands in a high quantum yield. The data obtained are consistent with the known theoretical approach, according to which the replacement of $\mathrm{C}-\mathrm{H}$ groups in the ligands with $\mathrm{C}-\mathrm{F}$ bonds results in an increase in the stability and luminescent activity of lanthanide emitters. The high luminescent activity of the Er, $\mathrm{Yb}$, and especially $\mathrm{Nd}$ complexes provides a basis for testing these materials in organic light-emitting diodes (OLED) as electroluminescent layers, as well as in the detectors of ionizing radiation, which will be the subject of further research.

Supplementary Materials: The following are available online. Figure S1: Packing motifs of $\mathrm{H}\left(\mathrm{SON}^{\mathrm{F}}\right)$, Figure S2: Fragment of crystal packing of 2. The $\mathrm{F}$ and $\mathrm{H}$ atoms are omitted for clarity, Figure S3: Fragment of crystal packing of 7. The $\mathrm{F}$ and $\mathrm{H}$ atoms are omitted for clarity, Figure S4: Photoluminescence spectrum of the gadolinium complex 1 at $77 \mathrm{~K}$, Figure S5: NIR PL kinetics of $\operatorname{Er}\left(\mathrm{SON}^{\mathrm{F}}\right)_{3}$ at $1530, \mathrm{Nd}\left(\mathrm{SON}^{\mathrm{F}}\right)_{3}$ at $1070, \mathrm{Sm}\left(\mathrm{SON}^{\mathrm{F}}\right)_{3}$ at 645 and $\mathrm{Yb}\left(\mathrm{SON}^{\mathrm{F}}\right)_{3}$ at $975 \mathrm{~nm}$. Excitation - Nd:YAG laser with $\lambda 355 \mathrm{~nm}$ (pulse duration $\sim 5 \mathrm{~ns}$ ). Red lines are fitting curves, Figure S6: The optimized geometry of 2, Figure S7: Normalized EPL, PL and absorption spectra of nonfluorinated and fluorinated scandium complexes in THF solution $\left(\lambda_{\text {exc }}=385 \mathrm{~nm}, 10^{-5} \mathrm{M}\right)$.

Author Contributions: Author contributions to the paper were as follows: T.V.B. and M.N.B. conceived and designed the research; T.V.B., M.E.B., V.A.I., R.V.R., G.K.F., A.N.Y. and B.A.A. performed the experiments and analyzed the data; A.A.S. performed quantum chemical calculations, A.V.M. completed the calculations of the lifetime of the theory of Judd-Ofelt, T.V.B. and V.A.I. wrote the manuscript; M.N.B. revised the manuscript. All authors read and approved the final manuscript.

Funding: This research was funded by the RSF (Grant No. 18-13-00066).

Acknowledgments: The work was performed using the instrumental base of the Analytical Center of the G.A. Razuvaev Institute of Organometallic Chemistry, Russian Academy of Sciences.

Conflicts of Interest: The authors declare no conflict of interest.

\section{References}

1. Kido, J.; Okamoto, Y. Organo Lanthanide Metal Complexes for Electroluminescent Materials. Chem. Rev. 2002, 102, 2357-2368. [CrossRef] [PubMed]

2. de Bettencourt-Dias, A. Lanthanide-based emitting materials in light-emitting diodes. Dalton Trans. 2007, 22, 2229-2241. [CrossRef] [PubMed]

3. Binnemans, K. Lanthanide-Based Luminescent Hybrid Materials. Chem. Rev. 2009, 109, 4283-4374. [CrossRef] [PubMed]

4. Eliseeva, S.V.; Bünzli, J.-C.G. Lanthanide luminescence for functional materials and bio-sciences. Chem. Soc. Rev. 2010, 39, 189-227. [CrossRef] [PubMed]

5. Bünzli, J.C.G.; Eliseeva, S.V. Lanthanide NIR luminescence for telecommunications, bioanalyses and solar energy conversion. J. Rare Earth. 2010, 28, 824-842. [CrossRef] 
6. Katkova, M.A.; Bochkarev, M.N. New trends in design of electroluminescent rare earth metallo-complexes for OLEDs. Dalton Trans. 2010, 39, 6599-6612. [CrossRef] [PubMed]

7. Bochkarev, M.N.; Vitukhnovsky, A.G.; Katkova, M.A. Handbook of Organic Laight-emitting Diodes (OLED); Decom: Nyzhny, Novgorod, 2011; pp. 1-364.

8. Tanner, P.A.; Duan, C.-K. Luminescent lanthanide complexes: selection rules and design. Coord. Chem. Rev. 2010, 254, 3026-3029. [CrossRef]

9. Feng, J.; Zhang, H. Hybrid materials based on lanthanide organic complexes: a review. Chem. Soc. Rev. 2013, 42, 387-410. [CrossRef]

10. Armelao, L.; Quici, S.; Barigelletti, F.; Accorsi, G.; Bottaro, G.; Cavazzini, M.; Tondello, E. Design of luminescent lanthanide complexes: From molecules to highly efficient photo-emitting materials. Coord. Chem. Rev. 2010, 254, 487-505. [CrossRef]

11. Bünzli, J.-C.G.; Piguet, C. Taking Advantage of Luminescent Lanthanide Ions. Chem. Soc. Rev. 2005, 34, 1048-1077. [CrossRef]

12. Wang, X.; Chang, H.; Xie, J.; Zhao, B.; Liu, B.; Xu, S.; Pei, W.; Ren, N.; Huang, L.; Huang, W. Recent developments in lanthanide-based luminescent probes. Coord. Chem. Rev. 2014, 273, 201-212. [CrossRef]

13. Bünzli, J.-C.G. Benefiting from the Unique Properties of Lanthanide Ions. Acc. Chem. Res. 2006, 39, 53-61. [CrossRef] [PubMed]

14. Reddy, M.L.P.; Sivakumar, S. Lanthanide benzoates: a versatile building block for the construction of efficient light emitting materials. Dalton Trans. 2013, 42, 2663-2678. [CrossRef] [PubMed]

15. Moore, E.G.; Samuel, A.P.S.; Raymond, K.N. From Antenna to Assay: Lessons Learned in Lanthanide Luminescence. Acc. Chem. Res. 2009, 42, 542-552. [CrossRef] [PubMed]

16. de Bettencourt-Dias, A.; Barber, P.S.; Viswanathan, S. Aromatic N-donor ligands as chelators and sensitizers of lanthanide ion emission. Coord. Chem. Rev. 2014, 273, 165-200. [CrossRef]

17. Kazakov, D.V.; Safarov, F.E. A novel chemiluminescence from the reaction of singlet oxygen with $\beta$-diketonates of europium(III), neodymium(III) and ytterbium(III). Photochem. Photobiol. Sci. 2014,13, 1646-1649. [CrossRef] [PubMed]

18. Reddy, M.L.P.; Divya, V.; Pavithran, R. Visible-light sensitized luminescent europium(III)- $\beta$-diketonate complexes: bioprobes for cellular imaging. Dalton Trans. 2013, 42, 15249-15262. [CrossRef]

19. Ma, Y.; Wang, Y. Recent advances in the sensitized luminescence of organic europium complexes. Coord. Chem. Rev. 2010, 254, 972-990. [CrossRef]

20. Katkova, M.A.; Balashova, T.V.; Ilichev, V.A.; Konev, A.N.; Isachenkov, N.A.; Fukin, G.K.; Ketkov, S.Y.; Bochkarev, M.N. Synthesis, structures, and electroluminescent properties of scandium N,O-chelated complexes toward near-white Organic Light-Emitting Diodes. Inorg. Chem. 2010, 49, 5094-5100. [CrossRef]

21. Katkova, M.A.; Pushkarev, A.P.; Balashova, T.V.; Konev, A.N.; Fukin, G.K.; Ketkov, S.Yu.; Bochkarev, M.N. Near-infrared electroluminescent lanthanide [Pr(III), Nd(III), Ho(III), Er(III), Tm(III), and Yb(III)] N,O-chelated complexes for organic light-emitting devices. J. Mater. Chem. 2011, 21, 16611-16620. [CrossRef]

22. Comby, S.; Bünzli, J.-C.G. Lanthanide Near-Infrared Luminescence in Molecular Probes and Devices. In Handbook on the Physics and Chemistry of Rare Earths; Elsevier: Amsterdam, The Netherlands, 2007; Volume 37, pp. 217-470.

23. Li, J.; Li, H.; Yan, P.; Chen, P.; Hou, G.; Li, G. Synthesis, crystal structure, and luminescent properties of 2-(2,2,2-Trifluoroethyl)-1-indone lanthanide complexes. Inorg. Chem. 2012, 51, 5050-5057. [CrossRef] [PubMed]

24. Raj, D.B.A.; Biju, S.; Reddy, M.L.P. Highly luminescent europium(III) complexes containing organosilyl 4,4,5,5,5-pentafluoro-1-(naphthalen-2-yl)pentane-1,3-dionate ligands grafted on silica nanoparticles. J. Mater. Chem. 2009, 19, 7976-7983.

25. Li, Z.; Dellali, A.; Malik, J.; Motevalli, M.; Nix, R.M.; Olukoya, T.; Peng, Y.; Ye, H.; Gillin, W.P.; Hernández, I.; et al. Luminescent Zinc(II) complexes of fluorinated benzothiazol-2-yl substituted phenoxide and enolate ligands. Inorg. Chem. 2013, 52, 1379-1387. [CrossRef] [PubMed]

26. Stenson, P. The crystal structure of 2-(o-hydroxyphenyl) benzothiazole. Acta Chem. Scand. 1970, 24, 3729-3738. [CrossRef]

27. Jia, A.-Q.; Jin, G.-X. Syntheses, characterization, and ethylene polymerization of titanium and zirconium complexes with [N, O] ligands. Dalton Trans. 2009, 8838-8845. [CrossRef] [PubMed] 
28. He, X.; Wu, Y.; Jin, W.; Wang, X.; Wu, C.; Shang, Y. Highly efficient $\mathrm{AgNO}_{3}$-catalyzed approach to 2-(benzo[d]azol-2-yl)phenols from salicylaldehydes with 2-aminothiophenol, 2-aminophenol and benzene-1,2-diamine. Appl. Organometal. Chem. 2018, 32, e4284. [CrossRef]

29. Janiak, C. A critical account on $\pi-\pi$ stacking in metal complexes with aromatic nitrogen-containing ligands. J. Chem. Soc 2000, 3885-3896. [CrossRef]

30. Balashova, T.V.; Pushkarev, A.P.; Rumyantcev, R.V.; Fukin, G.K.; Grishin, I.D.; Bochkarev, M.N. Heteroleptic 3-(2-benzothiazol-2-yl)-2-naphtholates of rare earth metals: Features of synthesis and structure. J. Organomet. Chem. 2015, 777, 42-49. [CrossRef]

31. Rumyantcev, R.V.; Fukin, G.K. Intramolecular C-F $\rightarrow$ Ln dative interactions in lanthanide complexes with fluorinated ligands. Russ. Chem. Bull. Int. Ed. 2017, 66, 1557-1562. [CrossRef]

32. Blatov, V.A.; Shevchenko, A.P.; Proserpio, D.M. Applied Topological Analysis of Crystal Structures with the Program Package ToposProCryst. Growth Des. 2014, 14, 3576-3586. [CrossRef]

33. Balashova, T.V.; Belova, N.A.; Burin, M.E.; Kuzyaev, D.M.; Rumyantcev, R.V.; Fukin, G.K.; Pushkarev, A.P.; Ilichev, V.A.; Shestakov, A.F.; Grishin, I.D.; et al. Substituted naphtholates of rare earth metals as emissive materials. RSC Advances. 2014, 4, 35505-35510. [CrossRef]

34. Balashova, T.V.; Pushkarev, A.P.; Ilichev, V.A.; Lopatin, M.A.; Katkova, M.A.; Baranov, E.V.; Fukin, G.K.; Bochkarev, M.N. Lanthanide phenolates with heterocyclic substituents. Synthesis, structure and luminescent properties. Polyhedron 2013, 50, 112-120. [CrossRef]

35. Burin, M.E.; Balashova, T.V.; Vorozhtsov, D.L.; Pushkarev, A.P.; Samsonov, M.A.; Fukin, G.K.; Bochkarev, M.N. Ate complexes of lanthanides with aryloxide ligands: Synthesis, structures, and luminescence properties. Russ. J. Coord. Chem. 2013, 39, 667-679. [CrossRef]

36. Shannon, R.D. Revised effective ionic radii and systematic studies of interatomic distances in halides and chalcogenides. Acta Cryst. 1976, 32, 751-767. [CrossRef]

37. Batsanov, S.S. Van der Waals Radii of Elements. Inorg. Mater. 2001, 37, 871-885. [CrossRef]

38. Henary, M.M.; Fahrni, C.J. Excited State Intramolecular Proton Transfer and Metal Ion Complexation of 2-(2'-Hydroxyphenyl)benzazoles in Aqueous Solution. J. Phys. Chem. A 2002, 106, 5210-5220. [CrossRef]

39. Roh, S.-G.; Kim, Y.-H.; Seo, K.D.; Lee, D.H.; Kim, H.K.; Park, Y.-I.; Park, J.-W.; Lee, J.-H. Synthesis, Photophysical, and Electroluminescent Device Properties of $\mathrm{Zn}(\mathrm{II})$-Chelated Complexes Based on Functionalized Benzothiazole Derivatives. Adv. Funct. Mater. 2009, 19, 1663-1671. [CrossRef]

40. Pushkarev, A.P.; Yablonskiy, A.N.; Yunin, P.A.; Burin, M.E.; Andreev, B.A.; Bochkarev, M.N. Features of spectral properties of $\mathrm{Sm}^{3+}$ complexes with dithia-and diselenophosphinate ligands. Spectrochim. Acta Part A Mol. Diomol. Spectrosc. 2016, 163, 134-139. [CrossRef]

41. Jayasankar, C.K.; Rukmini, E. Optical properties of $\mathrm{Sm}^{3+}$ ions in zinc and alkali zinc borosulphate glasses. Opt. Mater. 1997, 8, 193-205. [CrossRef]

42. Jayasankar, C.K.; Babu, P. Optical properties of $\mathrm{Sm}^{3+}$ ions in lithium borate and lithium fluoroborate glasses. J. Alloy. Compd. 2000, 307, 82-95. [CrossRef]

43. Walsh, B.M. Judd-Ofelt theory: principles and practices. In Advances in Spectroscopy for Lasers and Sensing; Di Bartolo, B., Forte, O., Eds.; Springer: Dordrecht, The Netherlands, 2006.

44. Kalyakina, A.S.; Sokolova, E.Y.; Vaschenko, A.A.; Lepnev, L.S.; Utochnikova, V.V.; Kuzmina, N.P. High Efficiency Organic Light-Emitting Diode Based on UV Stable Terbium Aromatic Carboxylates. Proc. SID Mid-Eur. Chapter Spring Meet. 2013, 1, 19-20.

45. Trivedi, E.R.; Eliseeva, S.V.; Jankolovits, J.; Olmstead, M.M.; Petoud, S.; Pecoraro, V.L. Highly emitting near-infrared lanthanide "encapsulated sandwich" metallacrown complexes with excitation shifted toward lower energy. J. Am. Chem. Soc. 2014, 136, 1526-1534. [CrossRef] [PubMed]

46. Kumar, G.A.; Riman, R.E.; Diaz Torres, L.A.; Banerjee, S.; Romanelli, M.D.; Emge, T.J.; Brennan, J.G. Near-Infrared Optical Characteristics of Chalcogenide-Bound $\mathrm{Nd}^{3+}$ Molecules and Clusters. Chem. Mater. 2007, 19, 2937-2946. [CrossRef]

47. Natrajan, L.S.; Timmins, P.L.; Lunn, M.; Heath, S.L. Luminescent Dinuclear Lanthanide Complexes of 5-Me-HXTA. Inorg. Chem. 2007, 46, 10877-10886. [CrossRef] [PubMed]

48. Pushkarev, A.P.; Ilichev, V.A.; Balashova, T.V.; Vorozhtsov, D.L.; Burin, M.E.; Kuzyaev, D.M.; Fukin, G.K.; Andreev, B.A.; Kryzhkov, D.I.; Yablonskiy, A.N.; et al. Lanthanide complexes with substituted naphtholate ligands: extraordinary bright near infrared luminescence of ytterbium. Russ. Chem. Bull. Int. Ed. 2013, 62, 392-397. [CrossRef] 
49. Hernandez, I.; Gillin, W.P. Organic Chromophores-Based Sensitization of NIR-Emitting Lanthanides. In Handbook on the Physics and Chemistry of Rare Earths; Elsevier: Amsterdam, The Netherlands, 2015; Volume 47, pp. 1-100.

50. Ilichev, V.A.; Silantieva, L.I.; Yablonskiy, A.N.; Andreev, B.A.; Rumyantcev, R.V.; Fukin, G.K.; Bochkarev, M.N. Synthesis, structure and long-lived NIR luminescence of lanthanide ate complexes with perfluorinated 2-mercaptobenzothiazole. Dalton Trans. 2019, 48, 1060-1066. [CrossRef] [PubMed]

51. Winkless, L.; Tan, R.H.C.; Zheng, Y.; Motevalli, M.; Wyatt, P.B.; Gillinet, W.P. Quenching of Er(III) luminescence by ligand C-H vibrations: Implications for the use of erbium complexes in telecommunications. Appl. Phys. Lett. 2006, 89, 111115. [CrossRef]

52. Shi, J.; Hou, Y.; Chu, W.; Shi, X.; Gu, H.; Wang, B.; Sun, Z. Crystal structure and highly luminescent properties studies of bis- $\beta$-diketonate lanthanide complexes. Inorg. Chem. 2013, 52, 5013-5022. [CrossRef]

53. Bischof, C.; Wahsner, J.; Scholten, J.; Trosien, S.; Seitz, M. Quantification of C-H quenching in near-IR luminescent ytterbium and neodymium cryptates. J. Am. Chem. Soc. 2010, 132, 14334-14335. [CrossRef]

54. Bradley, D.C.; Chotra, J.S.; Hart, F.A. Low co-ordination numbers in lanthanide and actinide compounds. Part I. The preparation and characterization of tris\{bis(trimethylsilyl)-amido\}lanthanides. J. Chem. Soc. Dalton Trans 1973, 1021-1023. [CrossRef]

55. Magde, D.; Wong, R.; Seybold, P.G. Fluorescence quantum yields and their relation to lifetimes of rhodamine 6G and fluorescein in nine solvents: Improved absolute standards for quantum yields. Photochem. Photobiol. 2002, 75, 327-334. [CrossRef]

56. Demas, J.N.; Crosby, G.A. Measurement of photoluminescence quantum yields. Review. J. Phys. Chem. 1971, 75, 991-1024.

57. Data Collection, Reduction and Correction Program; CrysAlisPro - Software Package; Agilent Technologies: Santa Clara, CA, USA, 2012.

58. SAINTPlus Data Reduction and Correction Program, version 6.45a; Bruker AXS: Madison, WI, USA, 2003.

59. Sheldrick, G.M. Crystal structure refinement with SHELXL. Acta crystallogr, Sect. C Struct. Chem. 2015, 71, 3-8. [CrossRef] [PubMed]

60. Sheldrick, G.M. SHELXT - Integrated space-group and crystal-structure determination. Acta crystallogr. Sect. A: Found. Adv. 2015, 71, 3-8. [CrossRef] [PubMed]

61. SCALE3 ABSPACK: Empirical absorption correction; CrysAlisPro - Software Package; Agilent Technologies: Santa Clara, CA, USA, 2012.

62. Krause, L.; Herbst-Irmer, R.; Sheldrick, G.M.; Stalke, D. Comparison of silver and molybdenum microfocus $\mathrm{X}$-ray sources for single-crystal structure determination. J. Appl. Cryst. 2015, 48, 3-10. [CrossRef] [PubMed]

63. Frisch, M.J.; Trucks, G.W.; Schlegel, H.B.; Scuseria, G.E.; Robb, M.A.; Cheeseman, J.R.; Scalmani, G.; Barone, V.; Mennucci, B.; Petersson, G.A.; et al. Gaussian 09, Revision E.01; Gaussian, Inc.: Wallingford, CT, USA, 2013.

64. Chemcraft. Available online: http://www.chemcraftprog.com (accessed on 7 August 2015).

Sample Availability: Not available.

(C) 2019 by the authors. Licensee MDPI, Basel, Switzerland. This article is an open access article distributed under the terms and conditions of the Creative Commons Attribution (CC BY) license (http://creativecommons.org/licenses/by/4.0/). 